\title{
Kvinder på krigsstien: Kvindelige palæstinensiske selvmordsbombere
}

\author{
Af Louise Lund Liebmann, ph.d.-studerende, Institut for Tvcerkulturelle og Regionale
} Studier, Københavns Universitet

Denne artikel er baseret på dele af mit religionshistoriske speciale fra 2008. Specialet 'Sprængfarlig feminisme - en analyse og diskussion af kvindelige palæstinensiske selvmordsbombere som politiske feminister' blev til på baggrund af feltstudier og indsamling af kildemateriale i IsraelPalæstina i sommeren 2007 og vinteren 2008. Artiklen er skrevet på baggrund af den del af specialet, der undersøger den lokale palæstinensiske og regionale arabiske fremstilling af kvinderne og argumenterer for, at den offentlige marginalisering af disse kvinder hænger sammen med et forsøg på at imødegå den kønskritik, der er involveret i kvindernes aktioner.

\section{Indledning}

Kvindelige palæstinensiske selvmordsbombere chokerer hele verden, når de dukker op i de internationale nyhedsmediers overskrifter. Den gængse profil på en potentiel selvmordsbomber, der ofte forstås som en fanatisk muslimsk mand, holder ikke længere stik, efter de unge palæstinensiske kvinder har tilsluttet sig den tidligere så mandsdominerede frihedselite. I nævnte rækkefølge har Wafa Idris, Dareen Abu Aisha, Ayat Akhras og Andaleeb Takatkah, Hiba Daraghmeh og Hanadi Jaradat, Reem al-Riyashi, Zainab Abu Salim, Fatma Omar an-Najar og Mirvat Masoud fra 2002-2006 sprængt sig selv og ofte civile israelere eller israelske soldater i luften i den palæstinensiske frihedskamps navn. Før Wafa Idris stod det mandlige monopol på selvmordsbomber uudfordret hen i Israel/Palæstina. ${ }^{\mathrm{i}}$

Samtidig går der sjældent en dag, uden diverse nyhedsmedier rapporterer om endnu en optrapning i konflikten mellem israelere og palæstinensere. Denne konflikt, der også er kendt som Mellemøstkonflikten, har enorm betydning for identitetsdannelser hos israelere og jøder såvel som palæstinensere, andre arabere og mange muslimer rundt om i verden. Da en palæstinensisk kvinde for første gang således gjorde sig selv til martyr ved en selvmordsbombeaktion en januardag i 2002, reagerede omverdenen med bestyrtelse Wafa Idris’ livshistorie blev dækket så massivt i både de vestlige og arabiske medier, at det var tydeligt for enhver, at hun via sin blodige handling havde overskredet barrierer og udfordret forventninger om, hvordan (palæstinensiske) kvinder bør opføre sig. Aktionen skabte også mulighed for nye identitetsdannelser for palæstinensiske kvinder, for flere fulgte hurtigt i Idris' fodspor. 
Det er dog bemærkelsesværdigt, at vold udført af kvinder får proportionelt mere opmærksomhed end vold udført af mænd, ligesom kvinders voldelige adfærd ofte diskuteres i forhold til de voldelige kvinders køn. Det sker sandsynligvis, fordi det underforstås, at voldelige kvinder opfører sig unaturligt (Sjoberg \& Gentry, 2007: 2). Men når kønnene således opdeles i den almene diskurs såvel som i forskningen, sker der en genindskrivning af den opfattelse, at mænds adfærd er normen, og at kvinders handlinger er noget 'andet'. En sådan behandling af emnet tager ikke højde for, at køn - ligesom religion kan være betydningsfuldt på alle niveauer af individets verdenskonstruktion, og at mænd og kvinder tolker deres tilværelse ud fra kønsspecifikke forudsætninger (Berger, 1967). Et manglende eksplicit fokus på kvinder og køn i kulturelle undersøgelser generelt og analyser om kvindelige palæstinensiske selvmordsbombere specifikt betyder, at der i mange eksisterende fremstillinger af kvindelige selvmordsbombere hersker implicitte kønsnormer, hvor kvinder som symbolske grænsevagter tillægges ekstra betydning som bærere af fællesskabets identitet og ære. Sådanne implicitte kønsnormer resulterer i en skævhed i de eksisterende fremstillinger af kvinderne. Netop for at rette op på denne skævhed, vil jeg i nærværende artikel benytte et eksplicit feministisk og postkolonialistisk perspektiv med brug af køn som analysekategori. Køn som analysekategori vil sige, at der tages højde for, at kvinder tolker deres tilværelse ud fra kønsspecifikke forudsætninger, og at kvinder derfor bør placeres centralt i analyser. Ligeså fungerer det postkolonialistiske perspektiv i denne sammenhæng som en analysemodel, der placerer ofte marginaliserede mennesker centralt $\mathrm{i}$ analysen $\mathrm{i}$ et forsøg på at udfordre den måde, hvorpå (den palæstinensiske) nationalisme portrætterer de kvindelige palæstinensiske selvmordsbombere. Den amerikanske kønsforsker og sociolog Frances Hasso og den israelsk fødte filmteoretiker Dorit Naaman er to af de forfattere, der netop benytter et eksplicit feministisk og postkolonialistisk perspektiv, som det forstås ovenfor. Derfor har jeg inddraget deres analyser af fremstillinger af kvindelige palæstinensiske selvmordsbombere $\mathrm{i}$ min egen undersøgelse og analyse af, hvordan de kvindelige palæstinensiske selvmordsbombere fremstilles i en national kontekst, samt hvilken rolle kvinderne spiller i den palæstinensiske nationalisme. 
Jeg har valgt at benytte politologen Benedict Andersons teori om nationalisme som et forestillet fællesskab, der erstatter det religiøse fællesskab. Sammen med sociologen Paul Connertons og historikeren Pierre Noras teorier om kollektiv erindring vil jeg benytte disse teorier som en metateoretisk ramme inden for hvilken, jeg vil analysere fremstillingen af de kvindelige palæstinensiske selvmordsbombere i en lokal palæstinensisk og regional arabisk kontekst. Teori om nationalisme og kollektiv erindring er yderst relevant $\mathrm{i}$ forhold til en analyse af de kvindelige selvmordsbombere, da de jo var en del af det palæstinensiske folk og samfund, der identificerer sig via en fælles nationalitet såvel som via fælles erindringer (Sa'di \& Abu-Lughod, 2007: 4). ${ }^{\text {ii }}$ Endvidere konstrueres kvinder ofte som kulturelle symboler på det nationale fællesskab, herunder som grænsemarkører, der med deres krop og opførsel markerer og udgør nationens identitet og ære. (Yuval-Davies, 1997: 67). Altså kommer mandens kulturelle og nationale identitet til udtryk gennem kvinden, som må kontrolleres (Wikan, 2003: 78). I forhold til modstands- og frihedskampe rundt om i verden er den nationalistiske konstruktion af kvindekøn meget betydningsfuld, idet magthavere har interesse $\mathrm{i}$ at konstruere nationen som homogen for at kunne opretholde idéen om et (forestillet) fællesskab. Disse konstruktioner falder imidlertid ikke altid $i$ kvindernes interesse, idet kvinder ofte befinder sig i en ambivalent position mellem nationen på den ene side og deres egne (kvindelige) interesser på den anden. Dette vil blive tydeliggjort i løbet af artiklen.

Det meste af artiklens arabiske kildemateriale skaffede jeg, da jeg i februar 2008 rejste til Israel/Palæstina for at hente arabisk kildemateriale og danne mig et indtryk af den palæstinensiske opfattelse af de kvindelige palæstinensiske selvmordsbombere. Under mit ophold ledte jeg efter martyrvideoer ${ }^{\text {iii }}$ med de kvindelige palæstinensiske selvmordsbombere. Men med en enkelt undtagelse har det ikke været muligt at skaffe videoerne, idet de lokale tv-stationer ikke ville eller kunne hjælpe. Desuden viste det sig kildemæssigt at være et meget vanskeligt tilgængeligt område, idet hverken NGO'ere eller andre organisationer havde arkiveret materiale om kvinderne - såsom pamfletter, testamenter og efterladte breve til familier og pårørende osv., som jeg ellers havde håbet på. Disse kilder ville jeg have brugt til en analyse af, hvordan de palæstinensiske kvinder selv opfattede og fremstillede deres selvmordsaktioner, - som modvægt til den forskning, der hovedsageligt 
baserer sig på vestlige, journalistiske skildringer. Men da dette ikke har været muligt, udgør mit arabiske kildemateriale i stedet martyrplakater, palæstinensiske modstandsgruppers samt palæstinensiske og øvrige arabiske avisartiklers fremstillinger af kvinderne, der vil blive brugt som grundlag for, hvordan kvinderne repræsenteres lokalt i de palæstinensiske områder og i de øvrige arabiske samfund.

I denne forbindelse er det dog væsentligt at nævne, at enhver undersøgelse af kvindelige palæstinensiske selvmordsbombere er baseret på andenhåndskilder, da intet andet er muligt. Det er derfor centralt, at vi ikke kan høre de kvindelige palæstinensiske selvmordsbomberes egne forklaringer. Kun uddrag fra de officielt sponsorerede og redigerede videoudtalelser, som kvinderne har efterladt, er tilgængelige for os. Der er derfor kun egentlig adgang til deres offentlige handlinger, det vil sige til selve selvmordsangrebet samt til venner og families retrospektive fortolkninger og til den måde, kvinderne og aktionerne bliver repræsenteret på af palæstinenserne selv eksempelvis i form af martyrplakater, der sættes op på husmure i Vestbredden og i Gaza. Både martyrplakater og mediernes fremstilling er imidlertid betydelige kommunikationsformer blandt palæstinenserne. Jeg vil desuden inddrage eksempler på nationalistisk, palæstinensisk litteratur i min analyse af den palæstinensiske fremstilling af kvinder og kvindelige palæstinensiske selvmordsbombere. Det gør jeg for at understrege, at den måde, palæstinensiske kvinder skildres på, ikke kun er en del af det palæstinensiske og øvrige arabiske mediebillede, men at repræsentationen også er udbredt i litteraturen og derfor omfatter væsentlige dele af den offentlige repræsentation. Men for at kunne sætte analysen ind i en kontekst, vil jeg i det følgende først redegøre for de teorier om nationalisme og kollektiv erindring, der lægger til grund for artiklens analyse, og derefter kontekstualisere den palæstinensiske nationalisme og de palæstinensiske kvinders rolle heri. Dernæst vil jeg analysere den offentlige fremstilling af de kvindelige palæstinensiske selvmordsbombere i de palæstinensiske og arabiske medier og på martyrplakater.

\section{Nationalisme som forestillet faellesskab og kollektiv erindring}

I det ansete værk Imagined Communities (1991) har Benedict Anderson defineret nationen som et forestillet politisk fællesskab. Anderson ser nationalisme og selve idéen om nationen som et alternativt fællesskab, der er opstået efter den franske revolution, da de 
eksisterende religiøse og dynastiske kulturelle systemer faldt sammen. Forestillingen om det nationale fællesskab, som en erstatning for et religiøst, får Anderson til at sidestille nationalisme med religion. Derfor mener han, at nationalisme netop skal studeres som religion, da han ikke ser nationalisme som en ideologi, men som en opfattelse af verden en ontologi. Nationen erstatter de tidligere slægtskabsbaserede samfund, hvilket medfører, at nationen kan opfattes som en stor familie, og det er ifølge Anderson en væsentlig grund til, at medlemmerne af det nationale fællesskab kan have så stærk en binding til nationen, at de er villige til at dø for den (Anderson, 1991: 5-12).

1700-tallet medførte desuden nye teknologier og opfattelser, som muliggjorde forestillingen om nationen. Bogtrykkerkunsten og en ændret opfattelse af tid og rum resulterede tilsammen i, at avisen og romanen også i dag giver folk en opfattelse af, at ting kan foregå samtidigt forskellige steder. Avisen skaber en forestillet forbindelse mellem læseren og det omtalte, mellem de omtalte og mellem alle avisernes læsere. Romanen giver læseren mulighed for at forestille sig personer, der er forbundet med hinanden i parallelle plot, og der er en form for samtidighed. Avisen og romanen er således med til at repræsentere det forestillede fællesskab, som nationen er. Ifølge Anderson er den nye opfattelse af tid analog med nationens opfattelse af sig selv; som en sociologisk organisme, der bevæger sig roligt gennem fortid, nutid og fremtid. Bogtrykkerkunsten og konstruktionen af de nationale sprog samt den ændrede opfattelse af tid er alle elementer, som medvirker til, at man ikke blot kan forestille sig, men også opretholde det forestillede nationale fællesskab (Anderson, 1991: 26).

Kollektiv erindring er én af de faktorer, der muliggør forestillingen om nationen som et fællesskab, og på denne måde er den en vigtig del af konstruktionen af en national identitet og en vigtig del, når nationen skal legitimere sig historisk. Erindringen er med til at skabe en national fortælling, som sikrer opretholdelsen af den følelsesmæssige tilknytning til nationen blandt befolkningen. Erindringen omfavner andre elementer som sprog, religion m.m., da forestillingen om det oprindelige sprog, den oprindelige religion osv. indlemmes og opretholdes gennem den kollektive erindring.

Den franske historiker Pierre Nora skelner i 'Between Memory and History: Les Lieux de Mémoire' (1989) mellem erindring og historievidenskab ved, at erindringen i hans forstå- 
else placerer minder i en sakral kontekst, hvorimod historien er en intellektuel aktivitet. Erindring er enten kollektiv eller individuel, og der eksisterer ligeså mange erindringer som fællesskaber (Nora, 1989: 8). I modsætning hertil tilhører historien alle og ingen, og den er derfor universel. Erindring er rodfæstet i det konkrete, det vil sige i rum, billeder eller objekter, mens historien forbindes med kontinuitet, forandring eller relationer mellem ting. Erindringen er desuden absolut, mens historien altid er relativ.

Ifølge Nora er lieux de mémoire, erindringssteder, levn fra dengang samfundet var milieux de mémoire, erindringsmiljøer, hvor erindringen var en reel del af hverdagsoplevelserne. Erindringssteder har den funktion, at de sikrer den kollektive erindring fra blot at være historie, ved at være legemliggørelse af den kollektive, erindrende bevidsthed. Erindringssteder er således det eksisterende, moderne samfunds eneste forbindelse til fortiden og tjener til at konstruere og bevare en kollektiv erindring og identitet (Nora, 1989: 12). Erindringssteder legemliggør erindring henholdsvis materielt, symbolsk og funktionelt alle tre vil dog altid fungere samtidig (Nora, 1989: 18-19). Lieux de mémoire er derfor hybride steder, der sammensætter liv og død, det tidlige og det evige. Ifølge Nora trives erindringsstederne, fordi de har en evne til at forandre sig - de kan genskabe gammel mening og generere ny betydning sammen med nye og uforudsigelige forbindelser. Erindringssteder kan være meget forskellige. Det kan være alt fra kirkegårde og museer til kalendere, undervisningsmateriale, film og billeder m.fl. (Nora, 1989: 22). Fælles er, at på grund af overgangen fra det præmoderne til det moderne samfund, der har medført erindringsfællesskabernes fald, findes den kollektive erindring kun i erindringsstederne, der er pejlemærker for den kollektive identitet. Erindringsstederne er samtidig i stand til at transcendere historien, idet evnen til at forandre sig og blive tillagt ny mening karakteriserer erindringssteder og adskiller dem fra historiske objekter.

Sociologen Paul Connerton er især interesseret i, hvordan man kan skabe eller manipulere med den kollektive erindring, og han beskæftiger sig med, hvordan erindringen overføres og opretholdes fra generation til generation. Glemsel er en vigtig del af erindring, for før erindring kan give mening, er vi nødt til at glemme begivenheder, der taler imod erindringen. For Connerton er glemsel simpelthen en central del af den menneskelige hukommelse, den menneskelige hjerne (Connerton, 2007: 12). Kollektiv erindring et resultat af en selektions- og eksklusionsproces, der er fundamental for mennesket som socialt 
væsen. Den kollektive erindring kan bruges og udnyttes politisk og ideologisk, fordi magthavere kan bruge magt til at organisere glemsel ved at basere sig på en historisk rekonstruktion og derigennem skabe en anden erindring (Connerton, 2007: 13-14). Det er dog centralt at bemærke, at Connerton understreger, at der sideløbende med den politisk herskende gruppes brug af magt til at organisere glemsel - og derigennem erindring også findes en mere uformel historisk produktion bestående af forskellige narrativer, der også er med til at danne individers erindring om samfundet (2007: 16-17). Den uformelle erindring kan dreje sig om uofficielle konventioner og udsagn - en uformel historie, der har betydning for befolkningen og den kollektive erindring.

Fælles for Connerton og Nora er, at der ifølge begge teoretikere eksisterer en kløft mellem nutid og fortid, der er resultat af en historisk proces. For dem er erindring en social konstruktion, som udføres og rekonstrueres over tid og hjælper nationens medlemmer til at opretholde deres forestillinger om (det forestillede) fællesskab.

\section{Palæstinensisk nationalisme og kollektiv erindring}

Uafhængighedskrigen 1948 eller Katastrofen, an-Nakba, som krigen hedder på arabisk, er blevet et hovedskel i den territorielle kamp om landet Israel/Palæstina og udformningen af nationale identiteter. Den palæstinensiske Nakba er den i dag dybt indgraveret i den nationale palæstinensiske bevægelses kollektive erindringer som et ultimativt eksempel på palæstinensernes rolle som ofre, og erindringen tjener også til at retfærdiggøre deres nationale kamp for Palæstina. ${ }^{\text {iv }}$ An-Nakba beskrives ofte som begyndelsen på den nuværende palæstinensiske historie - en historie om katastrofale forandringer, vold og undertrykkelse. An-Nakba er det historiske fikspunkt for palæstinensisk tid og et referencepunkt for andre historiske begivenheder i fortiden og fremtiden. Men samtidig udgør anNakba også oprettelsen af en slags ubestemt indre tid - en internalisering af forflyttelsen, der har at gøre med kollektiv erindring generelt og særligt den palæstinensiske kollektive erindring (Sa'adi \& Abu-Lughod, 2007: 5).

En karakteristisk kvalitet ved den palæstinensiske kollektive erindring er ifølge Mellemøstforskerne Ahmed Sa'adi og Lila Abu-Lughod dets orientering mod sted (Sa'adi \& Abu-Lughod, 2007: 13). For palæstinensere er Nakba-fortiden og området Palæstina enormt ladede - stederne er ikke kun almindelige erindringssteder, men også erindrings- 
steder i Pierre Noras forstand, idet stederne samtidig er symboler på alt, der blev tabt, og stederne udgør samtidig de fysiske, funktionelle rum, hvortil længslen og håbet om at vende hjem er knyttet. Den palæstinensiske tilknytning til steder er således både fysisk og forestillet. Det forestillingsmæssige har at gøre med, at krigen i 1948 og dets resultater endnu ikke er ovre, det er så at sige ikke fortid. Fysisk fordi konsekvenserne af krigen stadig er på spil, idet mange palæstinensere stadig lever i flygtningelejre eller i landflygtighed, og følelsesmæssigt og forestillingsmæssigt fordi eksil for palæstinenserne med sociologen Janet Abu-Lughods ord er en (...) nedarvet tilstand, der ikke er forbigående (Abu-Lughod, 1988: 63). An-Nakba og konsekvenserne deraf - enhver sten, der kastes, ethvert hus der rives ned, enhver bombe, der springer i luften i nutiden - er således en begivenhed, der på én gang er den samme og alligevel forskellig fra Katastrofen, idet disse begivenheder er en fortsættelse i konflikten mellem Israel og Palæstina.

De generationer af palæstinensere, der er vokset op efter an-Nakba, er vokset op i en kultur domineret af narrativer om Nakba, der går forud for deres fødsel. Der er dog ingen tvivl om, at overførslen af erindringerne herom er vedvarende, og man taler derfor om såkaldt 'posterindring' for at indfange, hvordan nutidens generation af palæstinensere er opvokset med narrativer, der ikke bare går forud i tid, men som også erstatter og undertrykker de senere palæstinensiske generationers historier, selvom disse senere generationers Nakba-erindringer i sagens natur ikke kan have noget med hukommelsen at gøre (Sa'di \& Abu-Lughod, 2007: 21).

Men senere generationer af palæstinensere har derimod deres egne erfaringer med besættelsesmagten, og de har i høj grad også konsekvenserne af Katastrofen tæt inde på livet, når de dagligt oplever racisme, vold og det fortsatte uløste problem med de palæstinensiske flygtninge (Sa'adi \& Abu-Lughod, 2007: 21). På denne måde sker der en slags fordobling af det forestillede palæstinensiske fællesskab, som den palæstinensiske nationalisme udgør, via erindring og posterindring. Det er nemlig yngre postNakba generationer af palæstinensere, der laver film og indsamler vidneudsagn om forflyttelsen, og det er samme generationer, der organiserer demonstrationer eller væbnet kæmper mod Israel og på denne måde historisk-diskursivt kæmper mod det dominerende zionistiske og historiske narrativ såvel som politisk og fysisk mod den israelske besættelsesmagt. 


\section{Det moderne martyrium i en palæstinensisk kontekst}

Selvmordsaktioner er blevet en væsentlig del af den palæstinensiske nationalisme og modstandsbevægelse. Men i en islamisk og palæstinensisk kontekst er der for kvinder (og mænd) ikke tale om selvmordsaktioner, men om martyraktioner, når de bevidst sprænger sig selv og ofte civile israelere i luften på israelsk jord eller ved israelsk-palæstinensiske grænseposter. Dette understreges først og fremmest ved, at den arabiske betegnelse for selvmordsaktioner, al-shahada, betyder 'gerninger, hvorunder martyriet søges' og intet har at gøre med det arabiske ord for selvmord, al-intihar (Dabbagh, 2005: 20; Cook, 2007: 32). Shahidtermen er ikke ny i den palæstinensiske modstandsdiskurs, men stammer fra den første intifada, hvor shahidbegrebet var selve ikonet på intifadaen. ${ }^{\mathrm{v}}$ I dag er istishhâd(yat) -udtrykket (martyr(inder)) det mest benyttede udtryk i de palæstinensiske områder i forbindelse med selvmordsaktionerne, og termen bruges af islamiske såvel som af sekulære grupper.

Man kan sige, at istishhâdihoperationer repræsenterer en særlig slags performance, der adskiller sig fra konventionel væbnet modstand ved hovedsageligt at ramme den israelske offentlighed. Ifølge den amerikansk-palæstinensiske antropolog Nasser A. Abufarha (2006: 299) betød introduceringen af istishhâdiyeenbegrebet, at ikonet på den første intifada - shahid - blev flyttet fra en offerposition til en heroisk placering i samfundet, idet offerets intentionalitet blev understreget. Det skal forstås på den måde, at shahidbegrebet ikke rummer offerintentionalitet, idet den, der søger martyriet, godt nok dør ved at forsvare sin nation, men betegnelsen gælder for alle, der er faldet for israelske kugler, og altså ikke udelukkende for selvmordsbombere. Istishadiiyeenbegrebet kommunikerer derimod en offerbetydning og tilføjer en ny islamisk betydning til betegnelsen (Abufarha, 2005: 300). I dag har istishhâdi således højere status i de palæstinensiske områder, end shahid har på grund af det heltemod, der tillægges intentionaliteten af martyrhandlingen (Abufarha, 2005: 361).

Martyriet, der også har relation til den klassiske islamiske teologi, er endvidere i en islamisk kontekst forbundet med jihaddoktrinens funktion om at mobilisere muslimer til at deltage i krige mod de vantro, da det anses for at være en fuldbyrdelse af den religiøse pligt, som det arabiske ord jihad knytter sig til ('at stræbe'). Denne motivation er stærkt influeret af idéen om, at den, der bliver dræbt på slagmarken, kaldet shahid(a) eller 
istishhâdi(yat), martyr(inder), vil komme direkte i paradis. Ved sådanne krigstilstande cirkulerer religiøse tekster normalt, heriblandt koranvers og hadithtekster, der udpensler fordelene ved at beskrive den belønning, der venter i paradis på dem, der er blevet dræbt under kamp (Peters, 2004: 15). Nedenstående citat er et eksempel på et korancitat, som ofte benyttes i forbindelse med martyriet: ${ }^{\mathrm{vi}}$

Og deres Herre bønhører dem: "Jeg lader ingen af jeres handlinger gå tabt, hverken mands eller kvindes; I hører sammen." De, der udvandrede og blev fordrevet fra deres huse; de, der har lidt overlast for Min sag; de, der kæmpede, og de, der blev dræbt, dem vil Jeg eftergive deres onde handlinger. Jeg vil føre dem ind i haver med rindende floder, som en belønning fra Gud. Hos Gud er den smukkeste belønning. (S3: 195)

Via denne begrebsafklaring er det tydeligt, at de vestlige udtryk 'selvmordsaktion' og 'selvmordsbomber' flytter fokus fra aktionens hensigt, - at søge martyriet via offeret til selve handlingen: At dø ved selvtægt. ${ }^{\text {vii }}$

Det moderne martyrium er imidlertid kun en del af den palæstinensiske nationalisme. Et andet sted, hvor forestillinger om det nationale fællesskab kommer til udtryk, er i litteraturen.

\section{Palæstinensiske kvinder i et nationalistisk perspektiv}

Benedict Andersons indflydelsesrige argument om, at nationer i virkeligheden blot er forestillede fællesskaber, understreger bl.a. litteraturens centrale rolle i forestillingen om nationen. I sin analyse af forskellige palæstinensiske romaner og legender, der alle omhandler livet som palæstinenser og den palæstinensiske nationalisme, viser litteraturforskeren Amal Amireh, at den offentlige, nationale palæstinensiske diskurs er fyldt med kønskonstruktioner (Amireh, 2003: 748). Det kønnede nationale narrativ er fokuseret på at konstruere, bruge og kontrollere både mænd og kvinders kroppe - den nationale identitet er kønnet, og nationen er så at sige fyldt af a priori opfattelser af maskulinitet og feminitet. Den palæstinensiske litterære fortælling er overordnet maskulin og erotisk, hvilket vil sige, at Palæstina associeres med en kvinde. Det palæstinensiske landbrugssamfunds afhængighed af moderlandets frugtbarhed har uden tvivl resulteret i brugen af en sådan metafor (Amireh, 2003: 749-750). Som i den nu afdøde palæstinensiske nationaldigter Mahmoud Darwishs velkendte digt 'A Lover from Palestine' fra 1966 sammenlig-

(C) Forfatteren og Tidsskrift for Islamforskning, ISSN 1901-9580, publiceret 15-03-2010 
nes palæstinenseren med den mandlige elsker, der længes efter den fortabte elskede, det fortabte land. Palæstina er i digtet en brud, og brudgommen er den palæstinensiske frihedskæmper og potentielle martyr, hvilket er en rollefordeling, Amireh også finder i romaner og intifadalegender (Amireh, 2003: 750).

Ved på denne måde at gøre landet til kvinden, bliver den nationale fortælling til historien om besiddelse af landet og mandens besiddelse af kvinden. Antropologen Rebecca Bryant foreslår, at det nationale slægtskab ikke blot skal forstås som en teori om historien, men at historien omvendt også tjener til at formulere en teori om nationalt slægtskab (Bryant, 2002: 509). Det vil sige, at de kønnede forestillinger, moderlandet Palæstina forbindes med i den palæstinensiske litteratur, betyder, at Palæstina forstås som medlem af den nationale familie og derfor personificeres i overensstemmelse med dette. Med til denne forestilling hører forestillingen om, at Palæstina og palæstinensere deler en form for substans, en essens. Denne fælles essens er så naturlig, at den tages for givet og kan derfor sammenlignes med forståelsen af mænd og kvinders grundlæggende, fælles substans. Men ligesom mænd og kvinder er forskellige, hersker der også forskelligheder mellem land og folk, og det er denne forskellighed, der udtrykkes i de kønnede forestillinger om nationen. På den måde kan den palæstinensiske elsker, manden, der længes efter sin elskede, Palæstina - i Darwishs digt ovenfor og i den øvrige nationalistiske litteratur opfattes som en bagvedliggende, hegemonisk, nationalistisk fertilitetsideologi, som marginaliserer størstedelen af de palæstinensiske kvinder, der ikke fremstilles som aktive palæstinensiske borgere, men tværtimod som passive livmodere, der skal tilbageerobres, besiddes og befrugtes.

Den palæstinensiske mands relation til landet og kvinden er desuden et tema i den palæstinensiske forfatter og PFLP-talsmand Ghassan Kanafanis klassiske novelle 'Men in the Sun', der foregår i 1958 (Kanafani, 1997). I den palæstinensiske - men også i den bredere arabiske - diskurs sammenlignes tabet af Palæstina ofte med en voldtægt af landområdet. Voldtægten symboliserer tabet af den kvindelige seksuelle uskyld og dermed tab af maskulin virilitet, fordi den virile aktør i sagens natur er voldtægtsforbryderen og fjenden. Tabet af Palæstina, der sammenlignes med voldtægten af den palæstinensiske kvinde, er altså en metafor for den kolonisering, der har fundet sted. Frygten for voldtægt af palæstinensiske kvinder spiller da også en meget central rolle i palæstinensiske kvinders Nak- 
baerindringer, om end de voldtægter af palæstinensiske kvinder, der rent faktisk fandt sted i 1948, er et tabubelagt emne, der udelukkes fra erindringerne (Humphries \& Khalili, 2007: 212). Tabuet skyldes, at den palæstinensiske opfattelse af familiebaseret ære hænger sammen med kvinders seksuelle eksklusivitet. ${ }^{\text {vii }}$

Også i forhold til den palæstinensiske modstandskamp, der voksede ud af det arabiske nederlag i forbindelse med Seksdageskrigen ${ }^{\text {ix }}$ i 1967, har de palæstinensiske kvinder haft en betydelig, men alligevel marginaliseret rolle. Overordnet udgøres modstandsbevægelsen på den ene side af de sekulære partier, der hører ind under PLO, og på den anden side udgøres bevægelsen af Hamas og Islamisk Jihad, der er karakteriseret ved at have en islamisk referenceramme. Både de religiøse og de sekulære bevægelser arbejder for et frit Palæstina og har på én gang givet kvinderne mulighed for at være med i den offentlige sfære samtidig med, at den nationale bevægelse ${ }^{\mathrm{x}}$ også har begrænset kvindernes aktivisme, idet den har betydet, at kvindernes prioriteter er blevet underlagt det nationale spørgsmål (Rasmussen, 2005: 24).

I forbindelse med krisesituationen under den første intifada, fik de palæstinensiske kvinder dog mulighed for at deltage i forsvaret af nationen. Det, der tidligere var blevet forbudt for de palæstinensiske kvinder - såsom aktiv deltagelse i voldelige aktioner - blev taget op til overvejelse, og det blev acceptabelt for kvinderne også at deltage på denne front, om end det nationalistiske spørgsmål hele tiden var førsteprioritet (Sjoberg \& Gentry, 2002: 116). Efter syv års intifada markerede Osloaftalen i 1993 imidlertid et vendepunkt i konflikten, og for de politisk aktive palæstinensiske kvinder svandt deres politiske råderum ind.

Palæstinensiske kvinders politiske deltagelse har altså været vedvarende og ofte betydelig, men den er ofte ikke blevet anerkendt. Selvom Palæstina har produceret forskellige kvindelige diplomater, er kvinder ikke blevet inkluderet i de formelle magtstrukturer i noget nævneværdigt omfang efter fredsforhandlingerne i 1993 (Moghadam, 2007: 342343). På den måde er palæstinensiske kvinder blevet marginaliserede i den nationale modstandsbevægelse. Det hænger ifølge sociologen Nira Yuval-Davis sammen med, at nationalitetskonstruktion indebærer specifikke opfattelser af manddom og kvindelighed. Kønsrelationer bliver ofte anset som grundlæggende for kulturessensen på grund af den 
sociale reproduktions betydning for kulturen, der videregives fra generation til generation. I den forbindelse er det særligt kvinder, der bærer repræsentationsbyrden, fordi kvinder bliver konstrueret som symbolske bærere af kollektivets identitet og ære. Herved personificerer kvinder i deres 'rette' opførsel, deres 'rette' tøj osv. den skillelinje, der markerer samfundets grænser (Davis, 1996: 39-47). Mens den palæstinensiske erindring er blevet undertrykt af det zionistiske narrativ, må man konstatere, at palæstinensiske kvinders stemmer er blevet dobbelt marginaliseret (Humphries \& Khalili, 2007: 209). I denne sammenhæng er det væsentligt at nævne, at Lila Abu-Ludghod har fremhævet, at kontrol er et vigtigt element i arabiske mænds maskulinitet, så i de forskellige narrativer, Amireh analyserer, men også i den palæstinensiske modstandsbevægelse og i sidste ende i det hegemoniske nationale narrativ, er den palæstinensiske kvindekrop at sammenligne med en 'national livmoder' (Enloe, 1989: 54). Den nationale livmoder er tilknyttet reproduktion af nationens fremtidige forsvarere, og samtidig er den palæstinensiske kvindekrop underlagt de palæstinensiske mænds kontrol på et tidspunkt, hvor mændenes egne kroppe er blevet udsat for overgreb og vold i relationen til Israel som besættelsesmagt (Amireh, 2003: 760).

\section{Palæstinensiske kvinder i et kollektivt erindrende perspektiv}

Også i forhold til den palæstinensiske kollektive erindring er de kvindelige palæstinensere marginaliserede. Antropologen Rosemary Sayigh har beskrevet, hvordan palæstinensiske kvinders fortællinger sjældent anerkendes som historie - både af dem selv og af andre. Litteraturteoretikeren Alessandro Portelli peger desuden på, at den palæstinensiske mands 'kampfortællinger' har forrang frem for den palæstinensiske kvindes 'hospitalsfortællinger', hvor de to køn fremhæver forskellige aspekter af deres erindringer (Humphries \& Khalili, 2007: 208). Kønnet er således bestemmende for de temaer, kvinder kan tale om i forbindelse med an-Nakba, der er en essentiel del af det palæstinensiske, nationalistiske metanarrativ. Kønnet er afgørende, fordi kvinder enten påbydes eller forbydes at tale om bestemte temaer (Humprhies \& Khalili, 2007: 210).

Undertrykkelsen af de palæstinensiske kvinders erindringer sker ofte, fordi de historier, de fortæller, destabiliserer og komplicerer etablerede nationalistiske narrativer, hvilket undertrykkelsen af visse palæstinensiske kvinders voldtægtserindringer i forbindelse med 
Katastrofen er et tankevækkende eksempel på. Desuden tilhører de førende palæstinensiske stemmer i det nationalistiske miljø politikere, militære ledere og folk med vestlig uddannelse, hvilket vil sige, at de førende palæstinensiske stemmer er maskuline. De kvinder, der rent faktisk fortæller deres historier og erindringer - eksempelvis om an-Nakba er generelt set fra de øvre samfundslag og er derfor ikke repræsentative for de mere jævne palæstinensiske kvinder fra flygtningelejre og landsbyer (Humpries \& Khalili, 2007: 209).

Den offentlige fremstilling og diskussion af de kvindelige palæstinensiske selvmordsbombere kan også ses i forlængelse af den palæstinensiske rolle og placering af kvinderne i den nationalistiske, palæstinensiske litteratur, idet Benedict Anderson allerede har fremhævet sammenhængen mellem avisernes og romanens nationaltilknyttende funktion. De palæstinensiske og arabiske mediers italesættelse af de kvindelige palæstinensiske selvmordsbombere må hænge sammen med, hvordan den palæstinensiske nationalisme og kønsforståelse tager sig ud. Som fortsættelse af analysen af palæstinensiske kvinders rolle og placering i det palæstinensiske samfund og i den palæstinensisk-arabiske diskurs, vil jeg i det følgende analysere fremstillingen af de kvindelige palæstinensiske selvmordsbombere i de palæstinensisk-arabiske medier.

\section{Den lokale offentlige fremstilling af de kvindelige palæstinensiske selvmordsbombe-} re

Overordnet har den arabiske verden forholdt sig tvetydigt til de kvindelige palæstinensiske selvmordsbombere. På den ene side reagerede store dele af den arabiske verden i kølvandet på de fire første kvindelige palæstinensiske selvmordsbombere især på de mere praktiske forhold i forbindelse med aktionerne. I de arabiske medier er det således blevet diskuteret, om kvinder kun må udføre selvmordsaktioner om dagen, så de ikke skal bevæge sig ud om aftenen og natten, hvor det ellers ikke er velanset, at de bevæger sig ud alene. Det har desuden været til diskussion, om de skal have en mahram (ledsager) med sig, som en sikkerhed for, at de ikke foretager sig noget, der kan bringe deres ære i tvivl. Ydermere har det været til debat, om kvinderne skulle have en tilladelse fra deres ægtemænd til at udføre en sådan aktion (Rasmussen, 2005: 64). 
På den anden side er deres aktioner blevet prist i de arabiske medier, og deres person er blevet genstand for ros, men blandt religiøse lærde har der dog været en del tvetydighed at spore. For begge grupper gælder det, at det er kvindernes køn, der har været genstand for den stillingtagen, der har været fremherskende. Hamas' daværende åndelige leder sheik Ahmad Yassin mente til at begynde med, at kvinder kun kunne fungere som en strategisk reserve, og at der måtte være visse restriktioner i forhold til kvinders selvmordsaktioner. Han begrundede sit synspunkt med, at der var rigeligt af frivillige palæstinensiske mænd, og derfor burde modstandsbevægelsen benytte sig af dem først. Efter et stykke tid ændrede han dog holdning, så han i stedet mente, at det var tilladeligt for kvinder at deltage, hvis de ikke opholdt sig mere end 24 timer uden for hjemmet i forbindelse med aktionen. Den indflydelsesrige egyptiskfødte tv-vært og medstifter af IslamOnline, sheik Yusuf al-Qaradawi fra Qatar, var dog mindre utvetydig, da han hævdede, at når muslimsk jord besættes, bliver jihadpligten gældende for begge køn, således at en kvinde sagtens kan deltage - uden sin mands tilladelse og uden at skulle tildække sit hår under aktionen (Rasmussen, 2005: 61-62).

Det er tydeligt, at kvindernes deltagelse imidlertid er blevet genstand for en diskussion, hvor andre aspekter end det rent taktiske eller rent etiske ved aktionen var en del af problematikken, og de palæstinensiske kvinders deltagelse blev fremhævet som noget særligt og noget andet end mændenes tilsvarende handlinger. De praktiske aspekter af selvmordsaktioner er således ikke et element i fremstillingen af de mandlige palæstinensiske selvmordsbombere, ligesom kønnet tilsyneladende ikke er relevant, når religiøse lærde diskuterer mænds selvmordsaktioner. Den særlige (kønnede) fremhævelse af kvindernes selvmordsaktioner ses også i forbindelse med den palæstinensiske modstandsbevægelses fremstilling af den enkelte kvindelige palæstinensiske selvmordsbomber og hendes aktion og den deraf følgende italesættelse af den respektive kvinde i de palæstinensiske og øvrige arabiske medier.

Eksempelvis tog Islamisk Jihad ansvar for Hanadi Jaradats aktion i 2003 og kaldte oversat fra arabisk aktionen for 'Haifas brud giver zionisterne en lærestreg, de ikke vil glemme' (Abufarha, 2006: 344). Hanadis brudeoperation har siden inspireret et enormt antal litterære produktioner lokalt i Palæstina såvel som regionalt i de øvrige arabiske lande. Men det er ikke kun Hanadi Jaradat, der er blevet fremstillet som Palæstinas brud lokalt 
eller i den øvrige arabiske verden. De palæstinensiske medier fremstiller generelt de kvindelige palæstinensiske selvmordsbombere som Palæstinas brude (Naaman, 2005: 945).

Kønsteoretikeren Frances Hasso mener, at de arabiske mænd, der generelt set er ophavsmændene til de forskellige fremstillinger, ønsker at fremstille kvinderne i overensstemmelse med deres kønsforståelser. Derfor konstruerer de fremstillingerne, så de passer med deres forventninger om kvindelige dyder såsom passivitet, skrøbelighed, heteroseksuel romantik og begær m.m., - hvilke alle er indeholdt i brudemetaforen. Hasso underbygger sit argument ved at vise, at brugen af brudemetaforen er selektiv og ikke gælder samtlige ti kvindelige palæstinensiske selvmordsbombere (Hasso, 2005: 42).

På den ene side er det tydeligt, at de kvindelige palæstinensiske selvmordsbombere hyldes som helte og martyrer lokalt såvel som regionalt, men på den anden side løftes de også op til et næsten mytisk niveau, der løser de problemer, der er forbundet med den utraditionelle kvindeopførsel i det traditionelle, palæstinensiske samfund. Fordi kvinder som tidligere nævnt er blevet accepteret i den nationale frihedskamp - vel at bemærke som symbol på moderlandet - er brugen af brudemetaforen belejlig i det patriarkalske nationalistiske projekt. Ved at benytte den velkendte nationalistiske brudemetafor minimerer arabiske mænd netop den potentielle kønskritik, der er indeholdt i kvindernes handlinger, ved i stedet at genindskrive et velkendt narrativ, der passer bedre på en traditionel patriarkalsk struktur (Naaman, 2005: 945-950).

Som i den øvrige palæstinensiske nationalistiske diskurs er brudemetaforen et yderst kønnet udtryk, der spiller på forforståelser af naturlige kvindelige egenskaber. Ligesom i den palæstinensiske litteratur indeholder sammenligningen af palæstinensiske kvinder med området Palæstina en traditionel rollefordeling, der dels viser, at den nationale identitet er kønnet, og dels at denne kønnede nationalidentitet fastholder de palæstinensiske kvinder i rollen som passive væsener, der i sidste ende skal tilbageerobres af de virkelige helte - de palæstinensiske mænd som i Darwishs digt ovenfor. Men selv når kvinderne $\mathrm{i}$ de offentlige fremstillinger ikke sammenlignes med nationens brude, spiller kvindekønnet alligevel en central rolle. Ofte fremhæves kvindernes moderlige og omsorgsfulde egenskaber, ligesom den pågældende kvindes livshistorie findes relevant for skildringen af 
den kvindelige palæstinensiske selvmordsbomber - som eksempelvis i en stor artikel i den palæstinensiske avis Daily Hayat:

Wafa kommer fra al-Amari flygtningelejren og er et medlem af Fatahbevægelsens komité for socialt arbejde i al-Amari lejren. Hun har boet hele sit liv i flygtningelejrens gader og stræder. Hun modtog sin folkeskoleundervisning i al-Amaris pigeskole, som er én af UNRWA-skolerne, og hun oplevede den besættelse, undertrykkelse og ydmygelse, som det palæstinensiske folk har gennemlevet, især fordi hun tilhørte en familie, der var flygtet fra deres oprindelige by al-Ramleh og nu bor i al-Amari lejren ved Ramallah [min oversættelse] (Daily Hayat, 2006:1)

Citatet illustrerer, at i fremstillingerne af de kvindelige palæstinensiske selvmordsbombere fremhæves kvindernes livshistorier, og på denne måde fremstilles Wafa Idris i et psykosocialt perspektiv, der underforstår, at det er hendes personlige tragiske historie, der er skyld i hendes overraskende handling. Citatet nævner Wafa Idris' opvækst i en palæstinensisk flygtningelejr lidt uden for Ramallah, ligesom hendes sociale engagement heller ikke forbigås. I resten af artiklen fremhæves desuden hendes arbejde for Røde Kors, og hendes kvindelige omsorg understreges ved at fremhæve, at hun som frivillig i Røde Kors' ambulancetjeneste behandlede sårede palæstinensere. Det passer implicit med artiklens fremhævelse af Wafa Idris' arbejde med at opdrætte fugle, hvilket endnu engang hentyder til Idris' omsorgsfulde egenskaber (Daily Hayat, 2006: 1). På denne måde er det tydeligt, at kønnet spiller en central rolle i skildringen af kvindelige palæstinensiske selvmordsbombere, selvom brudemetaforen ikke nødvendigvis nævnes.

Den uomtvisteligt kønnede, nationalistiske fremstilling er en del af det overordnede dominerende nationalistiske narrativ i den offentlige arabiske sfære, hvor de kvindelige palæstinensiske selvmordsbombere gøres til heteronome fortællinger om omsorgsfulde mødre og brude - narrativer der bekræfter og genindskriver en kønsstatus quo, der forbigår det kontroversielle og samfundskritiske element, der er til stede i kvindernes aktioner. Uanset om man taler om mytiske brude eller uhyrer, så er diskursen præget af, at emner som subjektivitet, agens og aggression udelades, fordi de er egenskaber, der ikke er klædelige for kvinder ud fra patriarkalske normer (Naaman, 2005: 946). I tråd med analysen af palæstinensiske kvinder i den nationale modstandsbevægelse og i den nationalistiske litteratur, må også den mediemæssige lokale og regionale fremstilling af de kvindelige 
palæstinensiske selvmordsbombere opfattes som en marginalisering af disse militante kvinder, der passer med den bagvedliggende, hegemoniske, nationalistiske fertilitetsideologi, som gennemstrømmer den øvrige nationalistiske diskurs. Undertrykkelsen af det samfundskritiske og kønskontroversielle element i forbindelse med fremstillingen af kvinderne og deres aktioner skal sandsynligvis ses i sammenhæng med undertrykkelsen af palæstinensiske kvinders Nakbaerindringer. Hvis de kvindelige palæstinensiske selvmordsbomberes agens og aggression understreges, kompliceres og destabiliseres den palæstinensiske kønsforståelse, der som ovenfor skitseret hænger snævert sammen med den nationalerindrende palæstinensiske identitet og selvforståelse. Derfor udelades, undertrykkes eller ignoreres det samfundskritiske potentiale i fremstillingen af kvinderne. Det svarer fuldstændigt til, at de palæstinensiske kvinders Nakbaerindringer er tilpasset de patriarkalske værdier, så det forestillede fællesskab, som aviserne - og de øvrige medier - er med til at skabe, fortsat konstruerer præcis det fællesskab, som den palæstinensiske, patriarkalske nationalisme længe har stået for og ikke forstyrrer den patriarkalske, nationalistiske diskurs og selvforståelse i noget nævneværdigt omfang.

Ligesom avisernes fremstilling af ugens martyrer(inder), er martyrplakater en væsentlig del af den offentlige fremstilling af nationalisme og det moderne martyrium lokalt i Palæstina. Samtidig er plakaterne en glimrende kilde til den palæstinensiske selvforstålse af de moderne martyrer, idet plakaternes brugskontekst og sprog, understreger, at de udføres med henblik på et lokalt palæstinensisk publikum.

\section{Martyrplakater}

At martyriet i dag er en væsentlig del af populærkulturen i Palæstina ses ikke blot ved tekstsamlinger som den ni bind store martyrologi Intifadat al-Aqsa, men også ved de martyrplakater, som produceres af forskellige palæstinensiske partier. Plakaterne er det førende medie, hvorigennem martyrkonceptet repræsenteres og kommunikeres i Gaza og på Vestbredden, selvom der eksempelvis også laves martyrkunst, kalendere og skrives martyrdigte, sange, graffiti og slogans m.m. (Patkin, 2004: 94). På én gang dokumenterer plakaterne martyriet og fungerer således som en indirekte nekrolog. Plakaterne er fyldt med klassiske, religiøse og nationalistiske referencer, og indholdet er overordnet det 
samme: Et fotografi af martyren, en nekrologtekst, der sædvanligvis indeholder et koranvers, samt forskellige islamiske og palæstinensiske symboler - ofte med billeder af Klippemoskéen i Jerusalem. Alt efter om partiet er islamisk eller sekulært, symboliserer moskéen enten Jerusalem som islams tredjehelligste by eller Jerusalem som Palæstinas hovedstad.

Martyrplakaterne, som de beskrives her, begyndte med den anden intifada, al-Aqsa intifadaen, og illustrerer, at palæstinensere er begyndt at repræsentere sig selv som modige helte i stedet for ofre. Efter palæstinenserne mistede håbet om at opnå større international støtte, da ansvaret for fredsprocessens fallit blev bebrejdet dem, er det palæstinensiske folks fokus skiftet fra international opmærksomhed til et behov for at blive anset som krigshelte lokalt i samfundet (Hashhash, 2006: 393).

På plakaten af Zainab Abu Salim, der blev den ottende kvindelige palæstinensiske selvmordsbomber, står navnet på den organisation, der udsendte hende, øverst på plakaten: al-Aqsa Martyrernes Brigade (Liebmann, 2008: 59). Al-Aqsa Martyrernes Brigade er en sekulær, militant organisation, der sympatiserer med Fatah-bevægelsen. Alligevel vises Zainab Abu Salim iført tørklæde foran Klippemoskéen, og ved siden af hende står der oversat fra arabisk 'Gud er stor'. Plakaten bekendtgør samtidig kvindens fulde navn: Zainab Ali Iyssa Abu Salim, og at hun er død som martyr for al-Aqsa Martyrernes Brigade, hvilket også illustreres af organisationens logo. Den billedmæssige og skriftlige information tjener på den ene side en funktion som en indirekte nekrolog, samtidig med at plakaten fejrer kvindens død og martyrium.

Religiøse og sekulære repræsentationer flyder på denne måde sammen på plakaten. For på den ene side bekendtgøres det, at det var en sekulær organisation, der sponserede det angreb, Salim foretog i 2004, men på den anden side vises Salims tørklædeklædte ansigt foran Klippemoskéen, der dog her sandsynligvis fremhæver Jerusalem som Palæstinas hovedstad og ikke Jerusalem som islams tredjehelligste by. 'Gud er stor' henviser til islamisk bøn og religionen islam, og koranen kan da også ses til højre for Salims ansigt. Det er bemærkelsesværdigt, at martyrplakater fra både sekulære og religiøse modstandsbevægelser altid mere eller mindre eksplicit indeholder et korancitat og på denne måde altid refererer til livet efter døden (Hashhash, 2006: 399). ${ }^{\text {xi }}$ Det arabiske sprog, der også 
altid bekendtgør de forskellige informationer på martyrplakaterne, har også en særlig sammenflydende funktion. Arabisk er på den ene side det sprog, der tales og skrives i de palæstinensiske områder, og på den anden side er det arabiske sprog også tæt knyttet til islam som religion, idet arabisk er koranens sprog og dogmatisk set det sprog, koranen blev åbenbaret på. At arabisk er det eneste sprog på denne og alle andre palæstinensiske martyrplakater illustrerer også, at plakaterne hovedsageligt laves med henblik på lokalt brug. Martyren Zainab Abu Salim fungerer på plakaten som ikon eller idol, der viser, at alle potentielt er modige helte, for hendes personlige historie fortælles ikke. Den undertrykkes og konfiskeres til fordel for kollektivets historie og viser, at utallige personlige historier kan genereres på denne måde, samtidig med at plakaten også skal inspirere andre til selvopofrelse.

Intet sted på plakaten er der nogen direkte reference til hverken død, selvmord eller zionisme, og det indikerer, at plakaten skal 'læses' i kontekst, -- at beskueren kun kan forstå martyrplakatens budskab ved at befinde sig i de områder, hvor plakaterne forefindes, og hvor fattigdommen, ødelæggelse, og skudhuller samtidig bevidnes og således kommer til at udgøre den medbetydning, der er yderst central for den måde, martyrbegrebet præsenteres og kommunikeres på. Zainab Abu Salims ansigt figurerer foran Klippemoskéen, og plakaten får hende på denne måde til at fremstå som beskytter af Jerusalem som Palæstinas hovedstad, som hun bogstaveligt talt har ofret sig for. ${ }^{\text {xii }}$

Ved at plakaterne tilbageholder direkte referencer til døden skjules og foreviges på samme tid døden som et brutalt faktum og som en konsekvens af selvmordsaktionen. I stedet sammenlignes martyriet implicit med evighed og det infinitte - som en slags fortsættelse af livet på jorden. Sommetider forstås evigheden som paradis, ${ }^{\text {xii }}$ hvilket især fremhæves af de islamiske modstandsbevægelser, men det er særligt den symbolske evighed, der hele tiden vedligeholdes i det palæstinensiske folks erindringer bl.a. via martyrplakaternes konstante påmindelse om martyrernes evige liv i form af deres visuelle overlevelse, der har betydning. På denne måde assimileres livet og døden på plakaten, samtidig med at det sekulære og religiøse som sagt også flyder sammen. Den palæstinensiske digter Mahmoud Abu Hashhash har bemærket, at der også sker en sammenflydning af barndom og voksenhed, ligesom en assimilering af det feminine og det maskuline, det offentlig og det private også er fremherskende på martyrplakaterne (Hashhash, 2006: 400). Det stemmer 
overens med, at det blot er Zainab Abu Salims usminkede ansigt, hendes hovedbeklædning og navn, der afslører, at det denne gang er en kvinde, der har begået et selvmordsangreb. På plakaten er der ingen andre referencer til selvmordsaktionen som en anderledes eller særlig feminin aktion.

An-Nakba er således ét element i den palæstinensiske kollektive erindring, mens de palæstinensiske martyrer og konstruktionen er disse er en anden og senere fornyelse af den palæstinensiske nationalisme, kollektive erindring og populærkultur. Pierre Noras understregning af, at lieux de mémoire legemliggør erindringen på tre forskellige måder, der dog altid fungerer samtidig - den materielle, symbolske og funktionelle - kan overføres på de palæstinensiske martyrplakater. Netop Noras meget brede definition af erindringssteder som alt fra fællesskaber, undervisningsmateriale og film til såvel mere konkrete steder såsom museer og kirkegårde, muliggør, at hans teori kan appliceres på kildematerialet. Hvis martyrplakater anskues som et erindringssted, er de både materielt, funktionelt og symbolsk et erindringssted, idet de både overleverer erindringen om palæstinensiske martyrer og dermed historien om den israelske besættelse, forflyttelsen af palæstinensere osv., og symbolsk, fordi de symboliserer hele den palæstinensiske modstandskamp og det palæstinensiske folks lidelser.

De fleste plakater blander det religiøse og det politiske i repræsentationen af martyren, og på denne måde politiseres religion og politik helliggøres, ligesom grænserne mellem børn og voksne, mænd og kvinder udviskes, så plakaterne fremstår som beviset på den inklusive og kollektive lidelse, der tjener til at forhindre glemsel og fortrængning via den kontinuerlige produktion af martyrplakater og dermed af visuelle narrativer (Hashhash, 2006: 402). Hvis martyrplakaterne læses som Pierre Noras lieux de mémoire, så sikrer disse erindringssteder den kollektive erindring ved simpelthen at udgøre den kollektive, erindrende bevidsthed, fordi plakaterne indeholder en medbetydning om hele det palæstinensiske folks historie og lidelser. Man kan altså sige, at den individuelle død komprimeres på plakaterne og gøres til et homogent offer, der tjener til at minde det palæstinensiske folk om, at de som folk er underlagt de samme risici og den samme skæbne. På denne måde vedligeholdes en myte om den homogene lidelsesnation (Allen, 2005: 94-95). Det er i denne sammenhæng, at de palæstinensiske selvmordsbombere og hele den tidligere 
nævnte populærkulturelle dyrkelse af martyrer bør anskues: Som det fremgår oven for, er de palæstinensiske selvmordsbomberes kamp også en frihedskamp og en kamp for nationen, der er viklet ind i en nationalreligiøs retorik, der retfærdiggør, opfordrer og løbende fornyer den kollektive erindring. For den kollektive erindring skal hele tiden holdes i hævd for at underbygge og vedligeholde det nationale fællesskab, der ligesom religion kan forstås som en menneskelighistorisk konstruktion. En konstruktion og en forestilling, som motiverer og muliggør den følelsesmæssige tilknytning til nationen, fædrelandet og til hinanden.

\section{Konklusion}

Ved hjælp af bl.a. Andersons, Noras og Connertons teorier har jeg analyseret litterære udgivelser, arabiske og palæstinensiske mediers skildringer såvel som martyrplakatens fremstilling af kvindelige palæstinensiske selvmordsbombere som kommunikationsformer, der skaber en forestillet forbindelse mellem læseren, beskueren og kvinderne. Avisen, litteraturen og martyrplakaten er således med til at repræsentere det forestillede fællesskab, som nationen er. På denne måde opstår og vedligeholdes en art myte om den homogene palæstinensiske lidelsesnation. Disse mytelignende fortællinger understreger den kollektive atmosfære og fremhæver nutiden som et øjeblik i historien, som enhver palæstinenser kan dele og relatere til.

Analysen af materialet har desuden vist, at den offentlige, nationale palæstinensiske diskurs er fyldt med kønskonstruktioner. Det kønnede nationale narrativ er fokuseret på at konstruere, bruge og kontrollere både mænd og kvinders kroppe - den nationale identitet er kønnet og nationen er fyldt af forforståelser af maskulinitet og feminitet. Det palæstinensiske nationalistiske metanarrativ er overordnet maskulin og erotisk, og Palæstina associeres og allegoriseres ofte som en kvinde, og fremstillingen af de kvindelige palæstinensiske selvmordsbombere tilpasses følgende det nationalistiske metanarrativ og den tilhørende kønsforståelse. Når de kvindelige palæstinensiske selvmordsbombere fremstilles som Palæstinas brude, muliggør fremstillingen, at kvindernes overraskende og kontroversielle kønsopførsel kan forbigås, idet de løftes op til et næsten mytisk niveau, når de hyldes og tiljubles som nationalhelte og martyrer. Selv når brudemetaforen ikke benyttes, 
spiller den kvindelige palæstinensiske selvmordsbombers køn alligevel en central rolle i fremstillingen, ligesom det er kvindernes køn, og de begrænsninger kvindekønnet giver i et traditionelt palæstinensisk samfund, der er blevet debatteret $i$ aviserne og af de religiøse lærde i den arabiske verden.

Kønnet er også centralt i forbindelse med martyrplakaternes fremstilling af kvinderne, selvom kvinderne ikke feminiseres på samme måde som i den øvrige skriftlige nationalistiske produktion. Netop Abu Salims usminkede og drengede fremtoning på plakaten kan således opfattes som en genindskrivning af den dominerende maskulinitet i martyrplakaterne, fordi den kvindelige palæstinensiske selvmordsbomber fremstilles som en drenget teenagepige og ikke en feminin kvinde. Dette fremstår som en modsætning til den ellers yderst kønnede og feminiserede fremstilling af palæstinensiske kvinder generelt i den litterære produktion og i den palæstinensiske modstandsbevægelse, men den drengede fremstilling af kvinderne på martyrplakaterne understreger alligevel palæstinensiske kvinders - og også de kvindelige palæstinensiske selvmordsbomberes -- marginale placering i den nationale diskurs og samfund. For netop martyrplakaternes fremhævelse af dyder som heltemod og opofrelse for nationen stemmer overens med den palæstinensiske opfattelse af maskulinitet. Derfor kan man argumentere for, at de særlige feminine og kvindelige træk undertrykkes på plakaterne til fordel for den nærmest ukønnede fremstilling af de kvindelige palæstinensiske selvmordsbombere. På denne måde er den offentlige, nationale palæstinensiske diskurs opdelt i forhold til de palæstinensiske selvmordsbombere. Når deres agens og aggressive adfærd understreges, som den gøres på martyrplakaterne, fjernes til gengæld kvindernes feminine træk. Disse feminine træk fremhæves ellers i stor stil i mediediskursen, men her benyttes brudemetaforen ofte, der som nævnt forbigår det samfundskritiske potentiale og det kontroversielle element $\mathrm{i}$ kvindernes opførsel. Det er fuldstændig i tråd med, at de palæstinensiske kvinder også er blevet marginaliseret i den palæstinensiske modstandsbevægelse, selvom kvinderne har haft en betydelig rolle deri. Modstandsbevægelsens marginalisering af kvinderne understreger i sidste ende det underlæggende tema i det hegemoniske nationale narrativ, hvor den palæstinensiske kvindekrop sammenlignes med en 'national livmoder', når kvindernes moderrolle løbende fremhæves. 
Forfatterpræsentation: Louise Lund Liebmann er cand.mag. i religionshistorie og historie fra Københavns Universitet fra 2008. Hun har i sine religionshistoriske studier bl.a. beskæftiget sig med islam, feminisme, kollektiv erindring og nationalisme.

\section{Abstract}

The paper analyses the local Palestinian and regional Arab representation of the $10 \mathrm{fe}$ male Palestinian suicide bombers and their actions. The Palestinian women, who detonated their suicide bombs in Israel or near Israeli-Palestinian borders from 2002-2006, thereby not only killed themselves, but often also Israeli soldiers and civilian Israelis in the name of the second Intifadah.

In the paper Benedict Anderson's theory on nationalism and Pierre Nora's and Paul Connerton's theories on collective memory - among others - serve as meta-analytical frameworks within which Palestinian nationalist literary productions, Palestinian-Arab media's account of the female Palestinian suicide bombers and martyr poster's representation of the violent women are analysed. The paper shows how the female Palestinian suicide bombers are marginalised and subordinated when the women's political agendas are submitted. I furthermore argue that conventional and stereotypical gender norms in the Palestinian-Arab portraits of the women are used to describe and evaluate the female suicide bombers in order to stabilize the potential gender criticism of the Palestinian society which is involved in the women's explosive and violent actions.

\section{Litteratur}

Abu-Lughod, Janet, 1988: Palestinians: Exiles at Home and Abroad. I: Current Sociology, 36, no. 2. Summer.

Abu-Lughod, Lila, 2008: Writing Women's Worlds - Bedouin Stories. University of California Press. (1. udg. 1993).

Adbo, Nahla, 2002: Women, War and Peace: Reflection from the Intifada. I: Women's Studies International Forum 25(5).

Abufarha, Nasser A., 2006: The Making of a Human Bomb: State Expansion and Modes of Resistance in Palestine. Ph-d ved University of Wisconsin, Madison.

Allen, Lori A., 2005: Suffering Through a National Uprising: The Cultural Politics of Violence, Victimization and Human Rights in Palestine. Ph-d ved University of Chicago, Illinois.

Allen, Lori A., 2000: The Polyvalent Politics of Martyr Commemorations in the Palestinian Intifada. History \& Memory. Vol. 12, no.12. Winter/Fall 2000.

(C) Forfatteren og Tidsskrift for Islamforskning, ISSN 1901-9580, publiceret 15-03-2010 
Amireh, Amal, 2003: Between Complicity and Subversion: Body Politics in Palestinian National Narrative. I: South Atlantic Quarterly 102: 4, Fall. Duke University Press.

Anderson, Benedict, 1991: Imagined Communities. Verso, London. (1. udgave 1983).

Berger, Peter L., 1967: Religion, samfund og virkelighed. Lindhardt og Ringhof, Viborg.

Bryant, Rebecca, 2002: The Purity of Spirit and the Power of Blood: A Comparative Perspective on Nation, Gender and Kinship in Cyprus. I: Royal Anthropological Institute. No 8.

Connerton, Paul, 2007: How Societies Remember. Cambridge University Press, London (1. udg.1989).

Cook, Davis, 2007: Martyrdom in Islam. Cambridge University Press, London.

Dabbagh, Nadia T., 2005: Suicide in Palestine - Narratives of Despair. Olive Branch Press, Massachusetts.

Daily Hayat, 2006: Martyrinden Wafa Idris. Daily Hayat, 26. januar, Ramallah.

Darwish, Mahmoud, 2003: Unfortunately, it was paradise - selected poems. University of California Press, Berkeley.

Davies, Nira-Yuval, 1997: Gender \& Nation. SAGE Publications Ltd, London.

Enloe, Cynthia, 1993: The morning after - sexual politics at the end of the Cold War. University of California Press.

Enloe, Cynthia, 1989: Bananas, Beaches, and Bases: Making Feminist Sense of International Politics. Berkeley: University of California Press.

Goldschmidt, Jr. Arthur, 2004: A Concise History of the Middle East. The American University in Cairo Press, Egypten.

Hashhash, Mahmoud Abu, 2006: On the Visual Representation of Martyrdom in Palestine. I: Third Text. Vol. 20, Iss. 3/4, May/July.

Hasso, Frances S., 2005: Discursive and political deployment by/of the 2002 Palestinian women suicide bombers/martyrs. I: Feminist Review. Vol. 81, 2005.

Humphries \& Khalili, 2007: Gender of Nakba Memory. I: Sa'di, Ahmad \& AbuLughod, Lila (red.) Nakba - Palestine, 1948, and the Claims of Memory. Columbia University Press, New York.

Jamal, Amal, 2004: Feminist Media Discourse in Palestine and the Predicaments of Politics. I: Feminist Media Studies 4 (2).

Kanafani, Ghassan, 1997: Men in the Sun and Other Palestinian Stories. Boulder, CO: Three Continents Press.

Kawar, Amal, 1996: Daughters of Palestine - Leading Women of the Palestinian National Movement. State University Press, New York.

Koranen. Oversat af Wulff, Ellen, 2006. Forlaget Vandkunsten, København.

Liebmann, Louise Lund, 2008: Sprcengfarlig feminisme - en analyse og diskussion af kvindelige palcestinensiske selvmordsbombere som politiske feminister. Speciale ved Institut for Tværkulturelle og Regionale Studier, Afdeling for Religionshistorie, Københavns Universitet. København.

Moghadam, Valentine M., 2007: Peace-Building and Reconstruction with Women - Reflections on Afghanistan, Iraq and Palestine. I: Moghadam, Valentine M. (red.): From Patriarchy to Empowerment - Women's Participation, Movements, and Rights in the Middle East, North Africa, and South Asia. Syracuse University Press, New York.

(C) Forfatteren og Tidsskrift for Islamforskning, ISSN 1901-9580, publiceret 15-03-2010 
Naaman, Dorit, 2007: Brides of Palestine/Angels of Death: Media, Gender, and Performance in the Case of the Palestinian Female Suicide Bombers. I: Signs: Journal of Women in Culture and Society. Vol. 32, no. 4, 2007.

Nome, Frida, 2003: Martyr Brigaderne. De Palcestinensiske Selvmordsbombere. Informations Forlag, København.

Nora, Pierre, 1989: Between Memory and History: Les Lieux des Mémoire. I: Representations, 26. Spring, The Regents of the University of California.

Patkin, Terri Toles, 2004: Explosive Baggage: Female Palestinian Suicide Bombers and the Rhetoric of Emotions. I: Women and Language. Vol. 27, no. 2.

Peters, Rudolph, 2004: Jihad i klassisk og moderne islam. Forlaget Vandkunsten, København. (1. udg. 1995).

Rasmussen, Gitte M., 2005: Palcestinensiske kvinder i kamp - En analyse af hvordan selvmordsbombere italescettes. Speciale ved Carsten Niebuhr afdelingen, Københavns Universitet.

Reem Riyashis martyrvideo, 2004: http://www.islamonline.net/arabic/adam/2004/01/Article08.shtml

Sa'di, Ahmad \& Abu-Lughod, Lila, 2007: Nakba-Palestina, 1948, and the Claims of Memory. Columbia University Press, New York.

Sayigh, Rosemary, 2007: Women's Nakba Stories: Between Being and Knowing. I: Sa'di, Ahmad \& Abu-Lughod, Lila (red.): Nakba-Palestine, 1948, and the Claims of Memory. Columbia University Press, New York.

Sjoberg, Laura \& Gentry, Caron E., 2007: Mothers, Monsters, Whores - women's violence in global politics. Zed Books, London.

Wikan, Unni, 2003: Are og drab. Fadime - en sag til eftertanke. Høst \& Søn, København.

\footnotetext{
${ }^{\mathrm{i}}$ Dog ikke andre steder. Både det kurdiske PKK, det tamilske LTTE og det tjetjenske RSRSBCM har med succes opmuntret kvinder til at deltage i denne form for politisk modstand i løbet af 1990'erne og i begyndelsen af det 21. århundrede, ligesom også kvinder fungerer som selvmordsbomber i dagens konflikthærgede Irak. Så kvinder er i høj grad en stadig aktiv og militant del af konflikter rundt om i verden.

${ }^{i i}$ De fælles erindringer handler hovedsageligt om den krig, israelere kalder Uafhængighedskrigen. Krigen førte i 1948 til staten Israels oprettelse, men krigen resulterede også i ødelæggelsen af det palæstinensiske samfund, idet mindst $80 \%$ af de palæstinensere, der levede på det landområde, hvor Israel blev etableret, blev flygtninge som resultat af krigen (Sa'di \& Abu-Lughod, 2007: 3).

iii Martyrvideoer er de videoer, som kvinderne har optaget inden deres selvmordsaktioner. I videoerne læser den pågældende kvinde op fra et på forhånd skrevet manuskript, hvori hun forklarer, hvorfor hun vil dø som martyr. Videoerne gør ofte brug af islamiske og nationalistiske referencer, ligesom man ud fra videoen ofte kan se, hvilken palæstinensisk modstandsorganisation, der har sponsoreret angrebet. Videoen afleveres efter angrebet til en lokal tv-station, der viser videoen. Efterfølgende er udklip fra videoerne ofte blevet vist i Israel og i den vestlige verden i diverse nyhedsudsendelser.

${ }^{\text {iv }}$ Palæstina betegner $i$ artiklen de palæstinensiske selvstyreområder Gaza og Vestbredden. Begrebet bruges som logisk følge af, at den arabiske befolkning, der bl.a. har tilknytning til disse områder, betegner sig selv som palæstinensere.

' Udtrykket 'shahid', der betyder 'martyr', var tilpasset samtidens politiske dynamik, hvor politikere forsøgte at lobbye det internationale samfund til at støtte palæstinensernes kamp for frihed. De palæstinensiske politikere ville have det internationale samfund til at presse Israel til at trække sig tilbage fra Vestbredden og Gaza og se på det palæstinensiske flygtningeproblem (Abufarha, 2006: 30). Udtrykket bruges til at referere til både kristne og muslimer til forskel fra istahhâdihtermen, der kun bruges om muslimske kombattanter.
}

(C) Forfatteren og Tidsskrift for Islamforskning, ISSN 1901-9580, publiceret 15-03-2010 
${ }^{\text {vi }}$ Mange af de korancitater, der ofte citeres i forbindelse med opfordring til at søge martyriet, kan altså ligesom den klassiske islamiske teologi siges at være såkaldt genderblind, idet det implicit forudsættes at martyren er en mand (Cook, 2007: 19).

vii Brugen af ordet 'selvmord' kommunikerer desuden, at personen, der udfører aktionen, er i en selvmordstruet, såkaldt suicidal, tilstand. Men den israelske psykiater Ariel Merari, der i mange år har forsket i de palæstinensiske selvmordsbomberes psyke, mener ikke, at hverken de kvindelige eller mandlige palæstinensiske selvmordsbombere er suicidale (Nome, 2001: 93). Så her er det tydeligt, at den vestlige diskurs er misvisende.

viii I den palæstinensiske kultur hænger mænds ære både sammen med landbesiddelse, men særligt familiens ugifte kvinders jomfruelighed. Familiens gifte kvinder skal udelukkende være seksuelt tilgængelige for deres respektive ægtemænd, hvis familiens ære skal opretholdes (Humphries \& Khalili, 2007: 212).

${ }^{\text {ix }}$ I Israel og i den vestlige verden kaldes krigen, der foregik i juni 1967, for Seksdageskrigen, men i de arabiske lande benævnes den 'al-Hazima', der betyder 'nederlaget'(Goldschmidt, 2004: 317-327).

x I denne artikel betegner begreber som 'modstandsbevægelse' og 'nationale bevægelse' osv. både de sekulære og de islamiske modstandsbevægelser, da det centrale i denne forbindelse er deres behandling og placering af de palæstinensiske kvinder.

${ }^{x i}$ Referencer til koranen giver legitimitet til repræsentationen af martyriet og dets metasprog.

xii Navnet 'al-Aqsa Martyrernes Brigade' refererer da også til al-Aqsa Moskéen i Østjerusalem.

xiii Koranen siger flere steder, at martyrer ikke skal forstås som døde, men som levende. Eksempelvis: "Du skal ikke regne med, at de, der blev drabt for Guds sag, er døde! Nej! De lever hos deres Herre og bliver forsørget" (S3: 169). 